\title{
Adıyaman İlinde Süt Üretim Çiftliklerinden ve Toplayıcılardan Sağlanan Sütlerin Bazı Özellikleri
}

\author{
Musa Serdar AKIN ${ }^{1 *}$, Öznur YAPIK ${ }^{2}$, Mutlu Buket AKIN ${ }^{1}$ \\ ${ }^{1}$ Harran Üniversitesi Ziraat Fakültesi Gıda Mühendisliği Bölümü, Şanlıurfa \\ ${ }^{2}$ Canpak Süt Endüstri Tekstil İnş. San. Tic. A.Ş \\ *Sorumlu yazar: sakin@harran.edu.tr
}

Öz

Bu araştırmada, Adıyaman ilinde kış, ilkbahar, yaz ve sonbahar mevsimlerinde farklı toplayıcılardan alınan 76 adet süt örneği ile süt üretim çiftliklerinden elde edilen 24 adet çiğ sütün bazı kimyasal ve mikrobiyolojik kaliteleri karşılaştırılmıştır. Süt üretim çiftliklerinden elde edilen toplam 24 adet çiğ sütün tamamına yakın bir kısmının titrasyon asitliği, kurumadde, yağsız kurumadde, protein ve özgül ağırlık değerleri Türk Gıda Kodeksi Çiğ ve Isıl İşlem Görmüş İçme Sütleri Tebliği'ne uygun bulunurken, toplam bakteri sayıları ise (\%79’u) uygun bulunmamıştır. Yine sütlerin kurumadde, yağsız kurumadde, protein, özgül ağırlık değerleri ve toplam bakteri sayıları üzerine mevsimin etkisi istatistiksel olarak önemli $(p<0.01)$ olurken, sadece titrasyon asitliği değerleri üzerine mevsimin etkisi önemsiz ( $p>0.05$ ) olmuştur. İncelenen toplam 76 adet süt örneğinin ise önemli bir kısmının titrasyon asitliği, kurumadde, yağsız kurumadde, protein,özgül ağırlık değerleri ve toplam bakteri sayıları bakımından Türk Gıda Kodeksi Çiğ ve Isıl İşlem Görmüş İçme Sütleri Tebliği'ne uygun bulunmamış ve sokak sütlerinin kimyasal ve mikrobiyolojik kalitelerinin yetersiz olduğu saptanmıştır. Sokak sütlerinin kimyasal özellikleri ve toplam bakteri sayıları üzerine mevsimin etkisi de önemli $(p<0.01)$ bulunmuştur.

Anahtar Kelimeler: Çiğ süt kalitesi, Adıyaman

\section{Some Properties of Raw Milk Obtained from Dairy Production Farm and Collectors in Adıyaman}

\begin{abstract}
In this study, the comparison of some chemical and microbiological qualities of 76 milk samples obtained from collectors and 24 dairy farm milk samples, which were taken in different parts of Adıyaman during winter, spring, summer and autumn, were aimed. The titratable acitidity, dry matter, non fat dry matter, protein and density of nearly all of the 24 milk samples, obtained from dairy farm, were adequate, but total bacterial counts of them (about 79\%) were not adequate the requirements in Turkish Food Codex. According to results, season had significant effect on the dry matter, non fat dry matter, protein, density and total bacterial counts $(p<0.01)$, but insignificant effect on the titratable acidity $(p>0.05)$. It was determined that the chemical and microbiological qualities of the most of the 76 milk samples obtained from collectors were not sufficient and the titratable acidity, dry matter, non fat dry matter, protein, density and total bacterial counts were not adequate the requirements in Turkish Food Codex. The effect of season on the titratable acidity, dry matter, nonfat dry matter, protein, density and total bacterial counts were found significant $(p<0.01)$.
\end{abstract}

Keywords: Raw milk quality, Adıyaman 


\section{Giriş}

Türkiye'de yılda 18.3 milyon ton civarında süt üretilmektedir. Üretilen sütün \% 42'si tüketiciye çiğ süt (sokak sütü/açık süt) olarak ulaşmaktadır. Modern işletmelerde işlenen süt oranı \% 18-20'dir. Hijyenik şartlara ne kadar uyduğu bilinmeyen mandıralarda işlenen süt miktarı ise \% 40'dır (TUiK, 2014).

$A B$ ülkelerinden Yunanistan'da üretilen sütün $\% 77^{\prime} \mathrm{i}$, İspanya'da $\% 78$ i, Danimarka ve Hollanda'da \%96'sı, İrlanda'da \%98'i kooperatifler ve diğer organizasyonlar aracılığı ile toplanarak soğuk zincir içerisinde ve hijyenik şartlarda sanayi kuruluşlarına verilerek işlenmektedir. Bu rakamlardan da anlaşılabileceği gibi çiğ sütün tüketiciye direkt ulaşması yani sokak sütçülüğü, gelişmiş ülkelerde çoktan unutulan ancak ülkemizde hala yaygın olan bir tüketim şeklidir (Ateş, 2015).

Türkiye'de üretilen ve herhangi bir Isıl işlem (pastörizasyon ve UHT) geçirmemiş sütün büyük bir oranı insan sağlığını tehdit eden çeşitli hastalık etkenlerini içermektedir. 28 Haziran 1995 tarih ve 22327 sayılı Resmi Gazetede yayınlanarak yürürlüğe giren "Gıdaların Üretimi ve Denetlenmesine Dair Kanun Hükmünde Kararname" ye dayanılarak çıkarılan ve 16 Kasım 1997 tarih ve 23172 mükerrer sayılı Resmi Gezetede yayınlanarak yürürlüğe giren "Türk Gıda Kodeksi Yönetmeliği"nin Yedinci Bölümünde yer alan hijyen ile ilgili kriterler, tüm gıda sektöründe olduğu gibi, süt ve süt ürünleri işleyen işletmelerin de uyması gereken hijyen kurallarını belirtmektedir. Türk Gıda Kodeksi Yönetmeliğinin 36. maddesine dayanılarak Sağlık Bakanlığı, Tarım ve Köyişleri Bakanlığı'nca ortaklaşa hazırlanan ve 14 Şubat 2000 tarih ve 23964 sayll Resmi Gazetede yayınlanarak yürürlüğe giren "Türk Gıda Kodeksi- Çiğ Süt ve Isıl işlem Görmüş İ̧̧me
Sütleri Tebliği" yayınlanmıştır. Bu tebliğin amacı, "çiğ sütün, ısıl işlem görmüş içme sütü, süt ürünleri ve süt bazlı ürünlerin tekniğine uygun ve hijyenik şekilde üretimi, depolanması, taşınması ve pazarlanmasını sağlamak üzere özelliklerinin belirlenmesidir. Ülkemizde süt ve süt ürünleri standartlarımızın bulunması ve denetlenmesine dair yasa ve yönetmelikler olmasına rağmen üretilen sütün $\% 42$ 'sinin açıkta satılan sokak sütü, $\% 40$ 'ının ise hijyen şartlarına uygun olmayan koşullarda işlenerek tüketiciye ulaşması düşünüldüğünde konunun sağlık açısından ne denli önemli olduğu ve hatta önemli bir halk sağlığı sorunu olduğu anlaşılacaktır (Kesenkaş ve Akbulut, 2010).

Ayrıca ülkemizde süt hayvancılığı ile uğraşan birimlerin küçük kapasiteli ve dağınık olması, mevsimler ve bölgelerden kaynaklanan üretim dengesizliği, sütün üretiminden işletmeye ulaştırılmasına kadar olan süre içinde hijyenik koşulların sağlanamaması ve soğuk zincir organizasyonunun kurulamaması da kaliteyi olumsuz etkilemektedir. Dolayısıyla ısıl işlem (pastörizasyon ve UHT) uygulanmak üzere işletmelere gelen sütlerin büyük kısmı fabrikaya ulaştığı anda ısıl işlem için uygun özellikleri taşımadığı görülmektedir (Kesenkaş ve Akbulut, 2010).

$\mathrm{Bu}$ araştırmada, Adıyaman'da bulunan özel bir süt işletmesine işlenmek üzere Adıyaman'ın farklı noktalarından ve çeşitli süt üretim çiftliklerinden kış, ilkbahar, yaz ve sonbahar mevsimlerinde işletmeye getirilen sütlerinin bazı mikrobiyolojik, fiziksel ve kimyasal özelliklerinin tespit edilmesi ve sokak sütlerinin kalitesi ile süt üretim çiftliklerinden getirilen sütlerin kalitelerinin karşılaştırıması amaçlanmış ve bu sütlerin kalitesine mevsimsel farklılıkların da etkisi belirlenmiştir. Elde edilen verilerin 
değerlendirilmesi; sokak sütçülüğünün daha önce yapılan araştırmalardan yola çıkarak kalitede herhangi bir gelişme olup olmadığını belirlemek, ayrıca çiftlik sütlerinin Türk Gıda Kodeksi Çiğ Süt ve Isıl işlem Görmüş içme Sütleri Tebliğine uygunluğunu ortaya koymak açısından önem taşımaktadır.

\section{Materyal ve Metot}

\section{Materyal}

Araştırmanın materyalini Kış (Ocak-Şubat), Ilkbahar (Nisan-Mayıs), Yaz (TemmuzAğustos) ve Sonbahar (Eylül-Ekim) mevsimlerinde Adıyaman'daki özel bir süt işleme tesisine işlenmek üzere işletmeye getirilen 19 (toplamda 76 örnek) süt örneği ile büyük ölçekli süt üretim çiftliklerden işletmeye getirilen 6 (toplamda 24 örnek) çiftlik sütü oluşturmuştur. Süt örnekleri 500 ml'lik steril cam şişelere yaklaşık 200-300 ml kadar alınarak ve buz kasetleri yardımıyla soğukta muhafazası sağlanarak, Harran Üniversitesi Ziraat Fakültesi Gıda Mühendisliği Bölümü laboratuvarlarına ulaştırılmıştır.

Metot

\section{Fizikokimyasal Analizler}

Sütlerde $\mathrm{pH}$ değerleri doğrudan inolab WTW (Weilheim, Germany) marka dijital pH metre kullanılarak saptanmıştır (Oysun, 2011). Çiğ sütlerde asitlik tayini alkali titrasyon yöntemi ile saptanmış ve sonuçlar \% laktik asit cinsinden ifade edilmiştir (Oysun, 2011). Çiğ sütlerde kurumadde oranları gravimetrik yöntem kullanılarak belirlenmiş ve sonuçlar \% olarak ifade edilmiştir (IDF, 1982). Yağ oranı 0-8 taksimatı özel süt bütirometresi ile Gerber yöntemine göre \% olarak belirlenmiştir (Anonim, 1989). Süt örneklerinde yağsız kurumadde oranı, toplam kurumadde değerinden yağ değerinin çıkarılmasıyla belirlenmiştir (Metin, 2010). Protein oranı, yaş yakmaya tabi tutulan örneklerin mikro Kjeldahl yöntemi ile azot miktarlarının saptanması ve bulunan azot miktarının 6,38 faktörü ile çarpılması ile hesaplanmıştır (IDF,1993). Süt örneklerinde özgül ağırık tayini laktodansimetre ile saptanmıştır (Oysun, 2011).

\section{Mikrobiyolojik Analizler}

Toplam aerobik mezofilik bakteri sayımı amacıyla dökme plak yöntemi kullanılarak PCA (Plate Count Agar, Merck) besiyerine paralel ekim yapılmıştır. Petri kutuları 32 ${ }^{\circ} C^{\prime}$ de 48 saat inkübe edilmiş ve sayım sonuçları logaritmik transformasyona tabii tutulduktan sonra log kob $\mathrm{ml}^{-1}$ olarak verilmiştir (Kesenkaş ve Akbulut, 2010).

\section{Istatistiksel Analizler}

Iki tekerrürlü olarak gerçekleştirilen denemede örneklerin fiziksel, kimyasal ve duyusal sonuçları SPSS 9.0 paket programı kullanılarak One Way Anova modeline göre istatistiksel analize tabi tutulmuştur. Örnekler arasında farklılık olup olmadığını saptamak için varyans analizi yapılıp, bu analizde önemli olanlar TUKEY testine tabi tutulmuştur (Bek ve Efe,1995).

\section{Araştırma Bulguları ve Tartışma}

$\mathrm{Bu}$ bölümde süt işletmesine gelen çiftlik sütleri ile sokak sütlerinin kimyasal ve bazı mikrobiyolojik özellikleri hem mevsimsel bazda birbirleriyle ve ülkemizdeki sokak sütlerinin kalitelerine yönelik daha önceki yıllarda yapılan diğer araştırmalarla hem de "Çiğ Süt ve Isıl İşlem Görmüş İçme Sütleri Tebliği"'nde belirtilen değerlerle karşılaştırılmış ve bulgular istatistiksel yönden de değerlendirilerek yorumlanmıştır. 
Çiftlik ve Sokak Sütlerinin Fizikokimyasal Özellikleri

\section{pH Değerleri}

Türk Gıda Kodeksi Çiğ ve Isıl İşlem Görmüş İçme Sütleri Tebliği'nde, sütün pH değerlerine yönelik herhangi bir değer belirtilmemiştir. Bununla birlikte süt teknolojisinde $\mathrm{pH}$ ölçümü asitliğin gelişebileceği her durumda tespit edilmelidir. Çünkü $\mathrm{pH}$ değeri ürünün kalitesi ve randımanı hakkında çok önemli ipuçları verir.

Araştırmada analize alınan çiftlik ve sokak sütlerine ait $\mathrm{pH}$ değerleri mevsimsel ortalamalar olarak Çizelge 1'de verilmiştir. Çiftlik sütlerinde $\mathrm{pH}$ değerleri 6.59 ile yaz mevsiminde en düşük bulunurken, 6.63 ile kış mevsiminde en yüksek bulunmuştur. Sokak sütlerinde de $\mathrm{pH}$ değerleri çiftlik sütlerinde olduğu gibi yaz mevsiminde en düşük 6.41 değeri tespit edilirken, kış sütlerinde ise en yüksek olarak 6.56 değeri tespit edilmiştir. Gerek çiftlik sütlerinin ve gerekse sokak sütlerinin $\mathrm{pH}$ değerlerine mevsimin etkisi istatistiksel olarak önemli $\quad(p<0.05)$ bulunmuştur.

Çiftlik ve sokak sütlerinin $\mathrm{pH}$ değerleri mevsimsel ortalamalar olarak karşılaştırıldığında, her iki süt çeşidi arasında önemli farklılıklar gözlenmiş ve bu farklılık istatistiksel olarak ta önemli $(p<0.05)$ bulunmuştur (Çizelge 1).

Bu araştırmada elde edilen çiftlik ve sokak sütlerinin $\mathrm{pH}$ değerleri, Türkoğlu ve ark. (2003) pH 6.66, Tokur (2006) pH 6.66 ve Özrenk ve Bayar (2008)'ın bulduğu pH 6.59 değerleri ile benzer olurken, Aydın ve ark. (2010) pH 4.46 ve Diler ve Baran, (2014)'ın bulmuş oldukları pH 5.93 değerlerinden daha yüksek olmuştur.

\section{Titrasyon Asitliği Değerleri}

Türk Gıda Kodeksi Çiğ ve Isıl İşlem Görmüş İçme Sütleri Tebliği'nde, çiğ inek sütlerinin
\%0.135 ile \%0.200 laktik asit arasında bir asitliğe sahip olması gerektiği bildirilmiştir. Asitliğin \%0.200 laktik asitin üzerinde olması mikrobiyal gelişmenin çok fazla olduğuna ve dolayısıyla çiğ süt kalitesinin yetersiz olduğuna işaret eder ve bu şekilde sütlerin ısıtıldığı anda pıhtılaşabileceğini gösterir.

Araştırmada analize alınan çiftlik ve sokak sütlerine ait titrasyon asitliği değerleri mevsimsel ortalamalar olarak Çizelge 1 'de verilmiştir. Çiftlik sütlerinin titrasyon asitliği değerleri ortalamalar olarak en düşük \%0.161 laktik asit ile kış mevsiminde tespit edilirken, en yüksek titrasyon asitliği değeri ise $\% 0.170$ laktik asit değeri ile yaz mevsiminde tespit edilmiştir. Çiftlik sütlerinin titrasyon asitliği değerlerinin tamamı, tebliğde titrasyon asitliği için bildirilen değerlere uygun bulunmuştur. Yapılan istatistiksel analizlerde çiftlik sütlerinin titrasyon asitliği değerleri üzerine mevsimin etkisi önemsiz ( $p>0.05)$ olarak belirlenmiştir.

Sokak sütlerinin titrasyon asitliği değerleri ise ortalamalar olarak en düşük \%0.182 laktik asit ile kış sütlerinde, en yüksek ise $\% 0.220$ laktik asit ile yaz sütlerinde saptanmıştır. Araştırmada toplayıcılardan temin edilen toplam 76 sokak sütü örneğinin \%50'si (kış sütlerinin \%26.3'ü, ilkbahar sütlerinin \%36.8'i, yaz sütlerinin $\% 84$ 'ü ve sonbahar sütlerinin \%52.6'sı) titrasyon asitliği değerleri bakımından tebliğe uygun bulunmamıştır. Yapılan istatistiksel analizlerde toplayıcılardan alınan süt örneklerinin titrasyon asitliği değerleri üzerine mevsimin etkisi önemli $(p<0.01)$ bulunmuştur. Özellikle sıcaklığın yüksek olduğu yaz ve sonbaharın ilk aylarında yetersiz soğutmaya ve mikrobiyal faaliyetlere bağlı olarak sütlerin asitliğinin yükseldiği tahmin edilmektedir. Mikrobiyolojik analiz sonuçları da bu kanıyı desteklemektedir. 
Çiftlik sütleri ve toplayıcılardan alınan sütlerin titrasyon asitliği değerleri mevsimsel ortalamalar olarak karşılaştırıldığında, süt çeşidinin sütlerin titrasyon asitliği değerleri üzerine etkisi istatistiksel olarak önemli $(p<0.01)$ olmuştur (Çizelge 1 ).

Konu ile ilgili olarak Türkiye'nin farklı yörelerinde sokak sütleri üzerinde yapılan araştırmalarda, araştırıcılar titrasyon asitliği değerlerini ortalamalar olarak, Sezgin ve Koçak (1982) \%0.189; Sezgin ve Bektaş (1988)
\%0.196; Türkoğlu ve ark. (2003) \%0.162; Özsunar (2005) \%0.170; Tokur (2006) \%0.165; Aydın ve ark. (2010) \%0.180; Kesenkaş ve Akbulut (2010) \%0.157 ve Tuncer (2015) \%0.225 laktik asit şeklinde tespit etmişlerdir. $\mathrm{Bu}$ araştırmada çiftlik sütlerinde tespit edilen titrasyon değerleri, diğer araştırıcıların bulmuş oldukları titrasyon asitliği değerleri ile benzer olurken, toplayıcılardan alınan sütlerde tespit edilen asitlik değerleri ise daha yüksek olmuştur.

Çizelge 1. Çiftlik ve Sokak Sütlerinin Bazı Fizikokimyasal Özellikleri

Table 1. Some Physicochemical Properties of Street and Farm Milks

\begin{tabular}{|c|c|c|c|c|c|}
\hline \multirow{3}{*}{$\begin{array}{l}\text { Özellik } \\
\text { Properties }\end{array}$} & \multirow{3}{*}{$\begin{array}{l}\text { Örnek } \\
\text { Sample }\end{array}$} & \multirow{2}{*}{\multicolumn{4}{|c|}{$\begin{array}{l}\text { MEVSIMLER } \\
\text { SEASONS }\end{array}$}} \\
\hline & & & & & \\
\hline & & $\begin{array}{c}\text { Kış } \\
\text { Winter }\end{array}$ & $\begin{array}{l}\text { İlkbahar } \\
\text { Spring }\end{array}$ & $\begin{array}{c}\text { Yaz } \\
\text { Summer }\end{array}$ & $\begin{array}{c}\text { Sonbahar } \\
\text { Autumn }\end{array}$ \\
\hline \multirow{3}{*}{$\begin{array}{l}\mathrm{pH} \\
\mathrm{pH}\end{array}$} & Çiftlik Sütleri & $6.63^{\mathrm{Bb}}$ & $6.61^{\text {Bab }}$ & $6.59^{\mathrm{Ba}}$ & $6.61^{\mathrm{Bab}}$ \\
\hline & Farm milks & & & & \\
\hline & $\begin{array}{l}\text { Toplayıcı Sütleri } \\
\text { Collector Milks }\end{array}$ & $6.56^{\mathrm{Ab}}$ & $6.49^{\mathrm{Aab}}$ & $6.41^{\mathrm{Aa}}$ & $6.45^{\mathrm{Aab}}$ \\
\hline $\begin{array}{l}\text { Titrasyon Asitliği } \\
\text { (\% laktik asit) }\end{array}$ & $\begin{array}{l}\text { Çiftlik Sütleri } \\
\text { Farm milks }\end{array}$ & $0.161^{\mathrm{Aa}}$ & $0.167^{\mathrm{Aa}}$ & $0.170^{\mathrm{Aa}}$ & $0.161^{\mathrm{Aa}}$ \\
\hline $\begin{array}{l}\text { Titratable acidity } \\
\text { (lactic acid \%) }\end{array}$ & $\begin{array}{l}\text { Toplayıcı Sütleri } \\
\text { Collector Milks }\end{array}$ & $0.182^{\mathrm{Ba}}$ & $0.196^{\text {Bab }}$ & $0.220^{\mathrm{Bc}}$ & $0.193^{\mathrm{Bbc}}$ \\
\hline Kurumadde (\%) & Çiftlik Sütleri & $13.28^{\mathrm{Ab}}$ & $12.49^{\mathrm{Aa}}$ & $12.33^{\mathrm{Aa}}$ & $12.69^{\mathrm{Aa}}$ \\
\hline \multirow[t]{2}{*}{ Dry matter (\%) } & Farm milks & & & & \\
\hline & $\begin{array}{l}\text { Toplayıcı Sütleri } \\
\text { Collector Milks }\end{array}$ & $11.53^{\mathrm{Bc}}$ & $10.51^{\text {Bab }}$ & $10.05^{\mathrm{Ba}}$ & $10.83^{\mathrm{Bb}}$ \\
\hline Yağ (\%) & Çiftlik Sütleri & $4.02^{\mathrm{Bb}}$ & $3.59^{\mathrm{Ba}}$ & $3.75^{\mathrm{Bab}}$ & $3.80^{\mathrm{Bab}}$ \\
\hline \multirow[t]{2}{*}{ Fat (\%) } & Farm milks & & & & \\
\hline & $\begin{array}{l}\text { Toplayıcı Sütleri } \\
\text { Collector Milks }\end{array}$ & $3.11^{\mathrm{Ab}}$ & $2.59^{\mathrm{Aa}}$ & $2.43^{\mathrm{Aa}}$ & $2.65^{\text {Aab }}$ \\
\hline \multirow{3}{*}{$\begin{array}{l}\text { Yağsız Kurumadde (\%) } \\
\text { Non fat dry matter (\%) }\end{array}$} & Çiftlik Sütleri & $9.25^{\mathrm{Bc}}$ & $8.91^{\mathrm{Bb}}$ & $8.58^{\mathrm{Ba}}$ & $8.89^{\mathrm{Bb}}$ \\
\hline & Farm milks & & & & \\
\hline & $\begin{array}{l}\text { Toplayıcı Sütleri } \\
\text { Collector Milks }\end{array}$ & $8.42^{\mathrm{Ac}}$ & $7.92^{\text {Aab }}$ & $7.62^{\mathrm{Aa}}$ & $8.18^{\mathrm{Abc}}$ \\
\hline \multirow{3}{*}{$\begin{array}{l}\text { Protein (\%) } \\
\text { Protein(\%) }\end{array}$} & Çiftlik Sütleri & $3.51^{\mathrm{Bb}}$ & $3.36^{\mathrm{Bab}}$ & $3.25^{\mathrm{Ba}}$ & $3.38^{\mathrm{Bab}}$ \\
\hline & Farm milks & & & & \\
\hline & $\begin{array}{l}\text { Toplayıcı Sütleri } \\
\text { Collector Milks }\end{array}$ & $3.14^{\mathrm{Ab}}$ & $2.76^{\mathrm{Aa}}$ & $2.65^{\text {Aa }}$ & $2.87^{\mathrm{Aa}}$ \\
\hline \multirow{3}{*}{$\begin{array}{c}\text { Özgül ağırlık }\left(\mathrm{g} \mathrm{ml}^{-1}\right) \\
\text { Density }\left(\mathrm{g} \mathrm{ml}^{-1}\right)\end{array}$} & Çiftlik Sütleri & $1.0328^{\mathrm{Bb}}$ & $1.0316^{\mathrm{Ba}}$ & $1.0311^{\mathrm{Ba}}$ & $1.0319^{\mathrm{Bab}}$ \\
\hline & Farm milks & & & & \\
\hline & $\begin{array}{l}\text { Toplayıcı Sütleri } \\
\text { Collector Milks }\end{array}$ & $1.0294^{\mathrm{Ac}}$ & $1.0263^{\mathrm{Ab}}$ & $1.0248^{\mathrm{Aa}}$ & $1.0266^{\mathrm{Ab}}$ \\
\hline
\end{tabular}




\section{Kurumadde Değerleri}

Türk Gıda Kodeksi Çiğ ve Isıl İşlem Görmüş İ̧me Sütleri Tebliği'nde direkt olarak kurumadde miktarı ile ilgili herhangi bir değer verilmemektedir. Araştırmada analize alınan çiftlik ve toplayıcılardan alınan sütlere ait kurumadde değerleri değerleri mevsimsel ortalamalar olarak Çizelge $1^{\prime}$ de verilmiştir. Çiftlik sütlerinin kurumadde değerleri ortalamalar olarak en düşük \%12.33 ile yaz sütlerinde, en yüksek ise \%13.28 ile kış sütlerinde tespit edilmiştir. Toplayıcılardan alınan sütlerin kurumadde değerleri ise mevsimsel ortalamalar olarak en düşük \%10.05 ile yaz sütlerinde, en yüksek ise \%11.53 ile kış sütlerinde tespit edilmiştir. Gerek çiftlik sütlerinin ve gerekse toplayıcılardan alınan sütlerin kurumadde değerlerine mevsimin etkisi istatistiksel olarak önemli $(p<0.01)$ bulunmuştur.

Çiftlik ve toplayıcılardan alınan sütler mevsimsel ortalamalar olarak birbirleriyle karşılaştırıldığında, her iki süt çeşidinin kurumadde değerleri arasında \%1.5-2.0 oranında bir farklılık olduğu gözlenmiş (Çizelge 1) ve bu farklılığın da istatistiksel olarak önemli $(p<0.01)$ olduğu belirlenmiştir.

Sokak sütleri üzerinde ülkemizin değişik yörelerinde yapılan birçok araştırmada araştırıcılar ortalama kurumadde değerlerini, Kavas ve Akbulut (1993) \%12.10; Özsunar (2005) \%13.00; Yaylak ve ark. (2007) \%12.08; Kesenkaşve Akbulut (2010) \%12.33 ve Kaşıkçı (2012) \%13.62 olarak bulmuşlardır.

Bu araştırmada çiftlik sütlerinde belirlenen \%12.33-13.28'lik kurumadde değerleri diğer araştırıcıların belirledikleri kurumadde değerleri ile uyum içinde olduğu gözlenirken, toplayıcılardan alınan sütlerde tespit edilen \%10.01-11.53'lük kurumadde değerleri diğer araştırıcıların buldukları kurumadde değerlerinden genelde daha düşük kalmıştır.

\section{Yağ Değerleri}

Süt yağı çok değerli bir besin maddesi olup pek çok faktörün etkisi altındadır. Hayvan ırkının yanı sıra hayvan tarafından tüketilen yemlerin kimyasal bileşimi de sütteki yağ miktarını önemli düzeyde etkilemektedir (Yalçın, 1981; Alçiçek, 1995; Şekerden ve Özkütük, 1995; Metin; 1998). Süt yağı, hem süt serumuna gevşek bir şekilde bağlı bulunduğundan, hem de özgül ağırlığı diğer süt bileşenlerine göre daha düşük olduğundan sütten kolaylıkla ayrılabilmektedir. Bu nedenle kasıtlı olarak süte yapılan müdahalelerle (süt yağının çekilmesi, süte su katılması vb.) sütün yağ miktarını düşürmektedir (Sezgin ve ark., 1993).

Türk Gıda Kodeksi Çiğ ve Isıl İşlem Görmüş İçme Sütleri Tebliği'nde yağ miktarı ile ilgili herhangi bir değer verilmemektedir.

Araştırmada analize alınan çiftlik ve toplayıcılardan alınan sütlere ait yağ değerleri mevsimsel ortalamalar olarak Çizelge 1'de verilmiştir. Çiftlik sütlerinin mevsimsel ortalamalar olarak en düşük yağ değerleri \%3.59 ile ilkbahar sütlerinde tespit edilirken, en yüksek yağ değerleri ise \%4.02 ile kış sütlerinde tespit edilmiştir. Bu durumun hayvanların yeşil yemle veye silajla beslenmesinden ve mevsimsel sıcaklık farkından kaynaklanabileceği tahmin edilmektedir.

Toplayıcılardan alınan sütlerde ise yağ değerleri mevsimsel ortalamalar olarak yağ değerleri kış, ilkbahar, yaz ve sonbahar sütlerinde sırasıyla $\% 3.11, \% 2.59, \% 2.43$ ve \%2.65 şeklinde belirlenmiştir. Yapılan istatistiksel analizlerde gerek çiftlik sütlerinin ve gerekse toplayıcılardan alınan sütlerin yağ değerlerine mevsimin etkisi istatistiksel olarak önemli $(p<0.01)$ bulunmuştur.

Çiftlik ve toplayıcılardan alınan sütler mevsimsel ortalamalar olarak birbirleriyle 
karşılaştırıldığında, her iki süt çeşidinin yağ değerleri arasında \%1.0-1.5 oranında bir farkın oluştuğu gözlenmiş (Çizelge 1 ) ve bu farklılığında istatistiksel olarak önemli $(p<0.01)$ olduğu tespit edilmiştir.

Araştırmamızda mevsimsel ortalamalar olarak çiftlik sütlerinde belirlenen \%3.59$4.02^{\prime}$ lik yağ değerleri konu ile ilgili olarak Türkiye'nin farklı yörelerinde sokak sütleri üzerinde yapılan araştırmalarda, diğer araştırıcıların bulmuş oldukları yağ değerleriyle Sezgin ve Koçak (1982) \%3.0; Sezgin ve Bektaş (1988) \%3.34; Kavas ve Akbulut (1993) \%3.30; Çubuk (1997) \%3.60; Türkoğlu ve ark. (2003) \%3.20; Özsunar (2005) \%4.08; Tokur (2006) \%3.17; Özrenk ve Bayar (2008) \%3.54; Aydın ve ark. (2010) \%3.47; Kesenkaş ve Akbulut (2010) \%3.79; Kaşıkçı (2012) \%5.68 ve Diler ve Baran (2014) \%3.60 uyum içinde olurken, toplayıcılardan alınan sütlerde tespit ettiğimiz \%2.43-3.11'lik yağ değerleri ise genelde diğer araştırmalarda elde edilen yağ değerlerinden daha düşük olmuştur.

\section{Yağsız Kurumadde Değerleri}

Sütün yağsız kurumaddesi belirli sınırlar arasında değişkenlik gösterdiğinden süte yapılan hilelerin belirlenmesinde önem taşımaktadır. Türk Gıda Kodeksi Çiğ ve Isıl İşlem Görmüş İçme Sütleri Tebliği'nde yağsız kurumadde ile ilgili bir değer belirtilmemiştir. Araştırmamızda çiftlik sütlerine ait yağsız kurumadde değerleri Çizelge 1 'de verilmiştir. Çiftlik sütlerinin mevsimsel ortalamalar olarak en düşük yağsız kurumadde değerleri \%8.58 ile yaz sütlerinde belirlenirken, en yüksek yağsız kurumadde değerleri ise \%9.25 ile kış sütlerinde belirlenmiştir. Yapılan istatistiksel analizlerde çiftlik sütlerinin yağsız kurumadde değerleri üzerine mevsimin etkisi önemli $(p<0.01)$ çıkmıştır. En yüksek yağsız kurumadde değerine sıcaklığın düşük olduğu ve hayvanların silajla beslendiği kış sütleri sahip olmuştur.

Toplayıcılardan alınan sütlerde mevsimsel ortalamalar olarak yağsız kurumadde değerleri kış, ilkbahar, yaz ve sonbahar sütlerinde sırasıyla $\% 8.42, \% 7.92, \% 7.62$ ve \%8.18 şeklinde belirlenmiştir. Yapılan istatiksel analizlerde toplayıcılardan alınan sütlerin yağsız kurumadde değerleri üzerine mevsimin etkisi önemli $(p<0.01)$ olmuştur. Özellikle yaz aylarındaki bazı örneklerde yağsız kurumadde değerinin çok düşük çıkması bu sütlere su katılmış olma ihtimalini düşündürmektedir.

Çiftlik ve toplayıcılardan alınan sütler mevsimsel ortalamalar olarak birbirleriyle karşılaştırıldığında, her iki süt çeşidinin yağsız kurumadde değerleri arasında \%0.7-1.1 oranında bir farkın oluştuğu gözlenmiş (Çizelge 1) ve bu farklılı̆ında istatistiksel olarak önemli $(p<0.01)$ olduğu tespit edilmiştir. Yapılan bazı araştırmalarda sütün yağsız kurumadde düzeyinin mevsimlere bağlı yem farklılı̆ından dolayı büyük varyasyon gösterdiği bildirilmektedir (Dozet ve ark., 1978; Juarez ve ark., 1978; Kılıç ve Kılıç, 1994).

Çubuk (1997) Ankara'da ilbahar ve sonbahar aylarında topladığı sokak sütü örneklerinde yaptığı araştırmasında, ilkbahar sütlerinin yağsız kurumadde oranlarının (\%8.30) sonbahar sütlerinden (\%8.75) daha düşük olduğunu belirlemiştir.

\section{Protein Değerleri}

Pratik açıdan sütteki protein oranının düşmesi süt ürünlerinde kalite sorunlarını da beraberinde getirdiğinden süttteki protein düzeyinin yüksek olması sütlerde arzu edilen bir niteliktir. Sütteki protein oranının değişimi süt yağı oranındaki değişim kadar fazla olmamasına rağmen yetersiz beslemenin, ırk, laktasyon dönemi ve süt verim düzeyi gibi faktörlerin protein oranı üzerinde etkili 
olduğu bildirilmektedir (Yalçın, 1981; Şekerden ve Özkütük, 1995). Türk Gıda Kodeksi Çiğ ve Isıl İşlem Görmüş İ̧̧me Sütleri Tebliği'nde, çiğ inek sütlerinin en az \%2.80 oranında protein içermesi gerektiği bildirilmiştir.

Çiftlik sütlerinin protein değerleri mevsimsel ortalamalar olarak en düşük \%3.25 ile yaz sütlerinde tespit edilirken, en yüksek protein değerleri ise \%3.51 ile kış sütlerinde tespit edilmiştir (Çizelge 1). Çiftlik sütlerinin protein değerleri gerek mevsimsel ortalamalar olarak gerekse analize alınan toplam 24 çiftlik sütü örneğinin hepsi (sütlerin $\% 100$ 'ü) tebliğde protein değeri için bildirilen \%2.80 değerinden yüksek olmuş ve tebliğe uygun bulunmuştur. Yapılan istatistiksel analizlerde çiftlik sütlerinin protein değerleri üzerine mevsimin etkisi önemli $(p<0.01)$ olarak belirlenmiştir.

Toplayıcılardan alınan sütlerin protein değerleri ise mevsimsel ortalamalar olarak en düşük \%2.65 oranı ile yaz sütlerinde, en yüksek ise \%3.14 oranı ile kış sütlerinde saptanmıştır. Araştırmada incelenen toplam 76 süt örneğinin $\% 35.5^{\prime} \mathrm{i}$ (kış sütlerinin \%5.3'ü, ilkbahar sütlerinin $\% 63.2^{\prime} \mathrm{i}$, yaz sütlerinin $\% 47.4^{\prime}$ ü ve sonbahar sütlerinin \%26.3'ü) protein değerleri bakımından tebliğde protein değeri için bildirilen \%2.80 değerine altında kalarak tebliğe uygun bulunmamıştır. Protein değerleri mevsimsel ortalamalar olarak değerlendirildiğinde ise kış ve sonbahar sütlerinin (\%3.14 ve 2.87) tebliğe uygun olduğu, ilkbahar ve yaz sütlerinin (\%2.76 ve \%2.65) ise tebliğe uygun olmadığı saptanmıştır. Yapılan istatistiksel analizlerde toplayıcılardan alınan sütlerin protein değerleri üzerine mevsimin etkisi önemli $(p<0.01)$ bulunmuştur.

Gönç ve Tanülkü (1981) ve Çubuk (1997) sütlerin protein değerlerinin kış aylarında diğer aylara göre daha yüksek olduğunu belirtmişlerdir.

Çiftlik ve toplayıcılardan alınan sütler mevsimsel ortalamalar olarak birbirleriyle karşılaştırıldığında, her iki süt çeşidinin protein değerleri arasında \%0.4-0.6 oranında bir farkın oluştuğu gözlenmiş (Çizelge 1) ve bu farklılığın da istatistiksel olarak önemli $(p<0.01)$ olduğu tespit edilmiştir.

Araştırmamızda mevsimsel ortalamalar olarak çiftlik sütlerinde belirlenen \%3.253.51'lik protein değerleri Özsunar (2005) \%3.60; Tokur (2006) \%3.36; Özrenk ve Bayar (2008) \%3.28 ve Aydın ve ark. (2010) \%3.28 bulmuş oldukları protein değerleriyle uyum içinde olurken, toplayıcılardan alınan sütlerde tespit ettiğimiz değerler Türkoğlu ve ark. (2003) \%2.98; Önal (2005) \%3.06; Yaylak ve ark. (2007) \%3.19; Kesenkaş ve Akbulut (2010) \%3.18; Kaşıkçı (2012) \%3.07 ve Diler ve Baran (2014) \%3.11 şeklinde buldukları değerlerle uyum içinde olmuştur.

\section{Özgül ağırlık Değerleri}

Süte yapılan hileler hakkında fikir sahibi olma açısından önemli ölçütlerden birisi de sütün yoğunluğudur. Sütün yoğunluğu, bileşiminde yer alan tüm maddelerin etkisiyle değişiklik gösterir. Yağ miktarının artması ile özgül ağırlık düşerken,yağ miktarının azalması ile özgül ağırlık yükselmektedir. Ayrıca protein, laktoz ve mineral madde miktarının artması ile özgül ağırlık artarken,sıcaklık artışı ise yoğunluğun düşmesine neden olur (Demirci ve ark. 2010). Türk Gıda Kodeksi Çiğ ve Isıl İşlem Görmüş İçme Sütleri Tebliği'nde çiğ inek sütlerinin özgül ağırlık değerleri ile ilgili olarak $1.028 \mathrm{~g}$ $\mathrm{ml}^{-1}$ değeri verilmektedir.

Araştırmamızda çiftlik sütlerine ait özgül ağırlık değerleri Çizelge 1 'de verilmiştir. Çiftlik sütlerinin mevsimsel ortalamalar olarak en düşük özgül ağırlık değerleri $1.0311 \mathrm{~g} \mathrm{ml}^{-1}$ ile 
yaz sütlerinde belirlenirken, en yüksek özgül ağırlık değerleri ise $1.0328 \mathrm{~g} \mathrm{ml}^{-1}$ ile kış sütlerinde belirlenmiştir. Mevsimsel ortalamalar olarak bakıldığında kış, ilkbahar, yaz ve sonbahar sütlerinin özgül ağırlık değerleri sırasıyla $1.0311 \mathrm{~g} \mathrm{ml}^{-1}, 1.0316 \mathrm{~g} \mathrm{ml}^{-1}$, $1.0311 \mathrm{~g} \mathrm{ml}^{-1}$ ve $1.0319 \mathrm{~g} \mathrm{ml}^{-1}$ bulunarak tüm değerler ilgili tebliğde belirtilen değerin $\left(1.0328 \mathrm{~g} \mathrm{ml}^{-1}\right)$ üzerinde olmuştur. Analize alınan toplam 24 çiftlik sütü örneğinin tamamı (örneklerin \%100'ü) tebliğde belirtilen 1.0280 $\mathrm{g} \mathrm{ml}^{-1}$ değerini sağlayarak tebliğe uygun bulunmuştur. Yapılan istatistiksel analizlerde çiftlik sütlerinin özgül ağıllık değerleri üzerine mevsimin etkisi önemli $(p<0.01)$ çıkmıştır.

Toplayıcılardan alınan sütlerin mevsimsel ortalamalar olarak özgül ağırlık değerleri kış, ilkbahar, yaz ve sonbahar sütlerinde sırasıyla $1.0294 \mathrm{~g} \mathrm{ml}^{-1}, 1.0263 \mathrm{~g} \mathrm{ml}^{-1}, 1.0248 \mathrm{~g} \mathrm{ml}^{-1} \mathrm{ve}$ $1.0266 \mathrm{~g} \mathrm{ml}^{-1}$ şeklinde belirlenirken, sadece kış sütleri tebliğde belirtilen $1.0280 \mathrm{~g} \mathrm{ml}^{-1}$ değerinin üzerinde kalarak tebliğe uygun bulunmuştur. İncelenen toplam 76 süt örneğinden ise 56 tanesi (örneklerin \%73.7'si) özgül ağırlık bakımından (kış sütlerinin $\% 10.5^{\prime} u$, ilkbahar sütlerinin $\% 94.7$ 'i, yaz sütlerinin $\% 100$ 'ü ve sonbahar sütlerinin $\% 89.5^{\prime} u$ ) tebliğe uygun bulunmamıştır. Yapılan istatiksel analizlerde toplayıcılardan alınan sütlerin özgül ağırlık değerleri üzerine mevsimin etkisi önemli $(p<0.01)$ olmuştur.

Çiftlik ve sokak sütlerinin mevsimsel ortalamalar olarak birbirleriyle karşılaştırıldığında, her iki süt çeşidinin özgül ağırlık değerleri arasında büyük farkın oluştuğu gözlenmiş (Çizelge 1) ve bu farklılı̆ın da istatistiksel olarak önemli $(p<0.01)$ olduğu tespit edilmiştir.

Konu ile ilgili olarak Türkiye'nin farklı yörelerinde sokak sütleri üzerinde yapılan araştırmalarda, araştırıcılar özgül ağırlık değerlerini ortalamalar olarak, Sezgin ve Koçak (1982) $1.0297 \mathrm{~g} \mathrm{ml}^{-1}$; Sezgin ve Bektaş
(1988) $1.0270 \mathrm{~g} \mathrm{ml}^{-1}$; Türkoğlu ve ark. (2003) $1.0315 \mathrm{~g} \mathrm{ml}^{-1}$; Özsunar (2005) $1.030 \mathrm{~g} \mathrm{ml}^{-1}$; Tokur (2006) $1.0296 \mathrm{~g} \mathrm{ml}^{-1}$; Yaylak ve ark. (2007) $1.0279 \mathrm{~g} \mathrm{ml}^{-1}$; Özrenk ve Bayar (2008) $1.0291 \mathrm{~g} \mathrm{ml}^{-1}$; Aydın ve ark. (2010) $1.0290 \mathrm{~g}$ $\mathrm{ml}^{-1}$; ve Diler ve Baran (2014) $1.0287 \mathrm{~g} \mathrm{ml}^{-1}$ şeklinde belirlemişlerdir.

Araştırmamızda mevsimsel ortalamalar olarak çiftlik sütlerinde belirlenen 1.0311$1.0328 \mathrm{~g} \mathrm{ml}^{-1}$ lik özgül ağırlık değerleri diğer araştırııların bulmuş oldukları özgül ağırlık değerlerinden genelde daha yüksek olurken, toplayıcılardan alınan sütlerde tespit ettiğimiz 1.0248-1.0294 $\mathrm{g} \mathrm{ml}^{-1}$ lik özgül ağırlık değerleri ise genelde diğer araştırmalarda elde edilen özgül ağırlık değerlerinden daha düşük olmuştur.

\section{Toplam Bakteri Sayıları}

Süt ve süt ürünlerinin de içerisinde yer aldığı çoğu gıdanın mikrobiyolojik analizinde en önemli nokta mezofil ve aerop koşullarda gelişen bakterilerdir.Kompleks biyokimyasal yapısı ve yüksek su kapasitesi nedeniyle çiğ süt, mezofil bakteriler olarak adlandırılan, saprofit veya patojen olabilen mikroorganizmalar için mükemmel bir ortamdır. Bu mikroorganizmalar gerek süt kalitesinin korunmasında gerekse çiğ süt üretiminden tüketimine kadar geçen süreçte hijyenik özelliklerin belirlenmesinde en önemli indikatörlerdendir (Üzüm, 2006). Türk Gıda Kodeksi Çiğ ve Isıl İşlem Görmüş İ̧̧me Sütleri Tebliği'nde çiğ inek sütlerinde toplam canlı bakteri sayısının $\left(30^{\circ} \mathrm{C}^{\prime} \mathrm{de}\right) \leq 100.000 \mathrm{kob}$ $\mathrm{ml}^{-1}$ olması gerektiği bildirilmiştir.

Araştırmamızda çiftlik sütlerine ait toplam bakteri sayıları Çizelge 2'de verilmiştir. Çiftlik sütlerinin mevsimsel ortalamalar olarak toplam bakteri sayıları kış, ilkbahar, yaz ve sonbahar sütleri için sırasıyla 5.24, 5.29, 5.74 ve 5.35 log kob ml-1 şeklinde belirlenmiştir. Analize alınan toplam 24 çiftlik sütü 
örneğinden 5 tanesi (örneklerin\%20.8'i) tebliğde belirtilen 5 log $\mathrm{kob} \mathrm{ml}^{-1}$ değerini sağlayarak tebliğe uygun bulunmuştur. Yapılan istatistiksel analizlerde çiftlik sütlerinin toplam bakteri sayıları üzerine mevsimin etkisi önemli $(p<0.01)$ çıkmıştır.

Toplayıcılardan alınan sütlerde ise mevsimsel ortalamalar olarak toplam bakteri sayıları kış, ilkbahar, yaz ve sonbahar sütlerinde sırasıyla $6.45,6.84,7.01$ ve 6.93 log kob $\mathrm{ml}^{-1}$ şeklinde belirlenirken, incelenen toplam 76 süt örneğinin 76 'sı da (örneklerin $\% 100$ 'ü) tebliğe uygun bulunmamıştır. Yapılan istatiksel analizlerde toplayıcılardan alınan sütlerin toplam bakteri sayıları üzerine mevsimin etkisi önemli $(p<0.01)$ olmuştur. Yaz aylarında toplam bakteri sayısının yüksek olması, mevsim sıcaklığının yüksek olmasına ve sütlerin işletmeye gelene kadar süreçte yeterince soğutulmamasına bağlı olarak mikroorganizma gelişiminin fazla olmasına bağlı olduğu düşünülmektedir.

Çizelge 2. Çiftlik ve Sokak Sütlerinin Toplam Aerop Mezofilik Bakteri Sayıları

Table 2. Total Aerob Mesophilic Bacteria Counts of Street and Farm Milks

\begin{tabular}{|c|c|c|c|c|c|}
\hline \multirow{3}{*}{$\begin{array}{l}\text { Örnek } \\
\text { Sample }\end{array}$} & & \multicolumn{4}{|c|}{$\begin{array}{l}\text { Toplam Aerop Mezofilik Bakteri Sayıları (log kob ml-1) } \\
\text { Total Aerob Mesophilic Bacteria Counts (log cfu ml-1) }\end{array}$} \\
\hline & & \multicolumn{4}{|c|}{$\begin{array}{l}\text { MEVSIMLER } \\
\text { SEASONS }\end{array}$} \\
\hline & & $\begin{array}{c}\text { Kış } \\
\text { Winter }\end{array}$ & $\begin{array}{l}\text { Illkbahar } \\
\text { Spring }\end{array}$ & $\begin{array}{c}\text { Yaz } \\
\text { Summer }\end{array}$ & $\begin{array}{l}\text { Sonbahar } \\
\text { Autumn }\end{array}$ \\
\hline \multirow{3}{*}{$\begin{array}{l}\text { Çiftlik Sütleri } \\
\text { Farm milks }\end{array}$} & $\begin{array}{l}\text { Min. } \\
\text { Min. }\end{array}$ & 4.89 & 4.89 & 5.49 & 4.89 \\
\hline & $\begin{array}{l}\text { Mak. } \\
\text { Max. }\end{array}$ & 5.64 & 5.65 & 5.91 & 5.61 \\
\hline & $\begin{array}{l}\text { Ort. } \\
\text { Mean }\end{array}$ & $5.24^{\mathrm{Ba}}$ & $5.29^{\mathrm{Ba}}$ & $5.74^{\mathrm{Bb}}$ & $5.35^{\mathrm{Bab}}$ \\
\hline \multirow{3}{*}{$\begin{array}{l}\text { Toplayıcı Sütleri } \\
\text { Collector milks }\end{array}$} & $\begin{array}{l}\text { Min. } \\
\text { Min. }\end{array}$ & 6.08 & 6.43 & 6.51 & 6.49 \\
\hline & $\begin{array}{l}\text { Mak. } \\
\text { Max. }\end{array}$ & 7.04 & 7.61 & 7.71 & 7.90 \\
\hline & $\begin{array}{l}\text { Ort. } \\
\text { Mean }\end{array}$ & $6.45^{\mathrm{Aa}}$ & $6.84^{\mathrm{Ab}}$ & $7.01^{\mathrm{Ab}}$ & $6.93^{\mathrm{Ab}}$ \\
\hline
\end{tabular}

*:Aynı satırda farklı küçük harfle gösterilen değerler istatistiksel olarak birbirinden farklıdır ( $\mathrm{p}<0.01)$

**: Sütunlar yukarıdan aşağıya incelendiğinde farklı büyük harfle gösterilen değerler istatistiksel olarak birbirinden farklıdır ( $p<0.01$ ).

Çiftlik ve toplayıcılardan alınan sütlerin mevsimsel ortalamalar olarak birbirleriyle karşılaştırıldığında, her iki süt çeşidinin toplam bakteri sayıları arasında 1.2-1.6 log kob $\mathrm{ml}^{-1}$ ’ık bir farkın oluştuğu gözlenmiş (Çizelge 1) ve bu farklılığın da istatistiksel olarak önemli $(p<0.01)$ olduğu tespit edilmiştir. $\mathrm{Bu}$ sonucun, çiftlik sütlerinin sağımdan işletmeye getirilene kadar ki süreçte daha hijyenik koşullarda tutulmasından ve daha iyi bir soğutma işlemi uygulandığından kaynaklandığı tahmin edilmektedir.

Araştırmamızda mevsimsel ortalamalar olarak çiftlik sütlerinde belirlenen 5.24-5.74 log kob $\mathrm{ml}^{-1}$ toplam bakteri sayılarının diğer araştırıcıların bulmuş oldukları toplam bakteri sayılarından daha düşük ve daha az değişken olduğu görülürken, toplayıcılardan alınan sütlerde tespit ettiğimiz 6.45-7.01 log kob m${ }^{1}$ toplam bakteri sayıları Ergüllü (1982) $8.5 \mathrm{log}$ kob $\mathrm{ml}^{-1}$ ve Dede (2000) 7.38 log kob ml-1 şeklinde buldukları toplam bakteri 
sayılarından daha düşük, Kesenkaş ve Akbulut (2010) 4.2-7.4 log kob ml-1 ile Diler ve Baran (2014) $5.29 \mathrm{log} \mathrm{kob} \mathrm{ml}^{-1}$ olarak buldukları değerlerden daha yüksek olmuştur.

\section{Sonuçlar}

Türkiye'de son yıllarda giderek artan sayıda büyük ölçekli işletmeler, süt ve süt ürünleri üretiminde faaliyet göstermeye başlamıştır. Söz konusu işletmeler oldukça modern ve hijyenik tesislerde sütü işlemekte ve gıda güvenlik kurallarına uymaktadırlar. Bu sayede gelişen süt endüstrisi ile kurulan toplama merkezlerinde ise sütün soğuk zincir oluşturularak kontrollü olarak toplanması sağlanmıştır. Böylece sütün fiziksel kimyasal açıdan doğal faktörler dışında meydana gelebilecek değişimler önlenmiş ve mikrobiyal açıdan olabilecek bulaşmalar en aza indirilmiştir. Ancak süt endüstrisindeki gelişmeler ve süt kalitesi ile hijyen kurallarını dikkate alarak üretim yapan orta ve büyük ölçekli süt üretim çiftlikleri bile sokak sütçülüğünün önüne geçememiştir.

Bunun altında yatan sebepler; modern süt işletmelerinin topladığı sütün önemli bir bölümünü küçük ölçekli aile işletmelerinden sağlaması, tüketicinin önemli bir kısmının sokak sütünü saf, taze ve doğal olduğu yanılgısıyla tercih etmesi, sokak sütü fiyatının göreceli olarak düşük olması ve tüketiciye sürekli ulaşılabiliyor olmasıdır.

Araştırmamızda ele aldığımız 100 süt örneğinde yapılan fizikokimyasal ve mikrobiyal analizler, Adıyaman ili ve çevresinde farklı kaynaklardan toplanan çiğ süt örneklerinin kalitelerinin yeterli düzeyde olmadığını, önemli bir kısmının Türk Gıda Kodeksi Çiğ ve Isıl İşlem Görmüş İçme Sütleri Tebliği'ne uymadığını göstermektedir.

Mevsimin örneklerin bileşimini önemli düzeyde etkilediği belirlenmiştir $(p<0.01)$. Özellikle sıcaklığın düşük olduğu kış aylarında üretilen sütlerin kalitesinin daha iyi olduğu tespit edilmiştir. Gerek taşıma ve gerekse depolama sırasında soğutma koşullarının iyileştirilmesi ile sıcaklığın oldukça yüksek olduğu yaz aylarında üretilen sütlerin kalitesinin de iyileşeceği düşünülmektedir.

Çiftliklerde üretilen sütlerin sağımından işletmeye ulaşana kadar geçirdiği süreçte hijyenik kurallara daha çok dikkat edildiği ve özellikle soğutmanın iyi yapıldığı, hilelerden kaçınıldığı tahmin edilmekte ve bu nedenle süt kalitesinin toplayıcılardan alınan sütlerden daha iyi olduğu düşünülmektedir. Elde edilen sonuçlar değerlendirildiğinde incelenen örneklerin kimyasal özelliklerinden ziyade mikrobiyal kalitelerinin daha kötü olduğunu söylemek mümkündür.

Örneklerin elde edildiği kaynaklar ayrı ayrı ele alındığında ise incelenen toplayıcılardan alınan süt örneklerinin yaklaşık \% 91'inin mikrobiyal kalite bakımından yetersiz olduğu tespit edilmiştir. Bu rakam orta ve küçük ölçekli süt çiftliklerinde \% 50'ye kadar düşmektedir.

Sonuç olarak, Adıyaman ili ve çevresinde çiğ süt kalitesi ve toplum sağlığı bakımından önemli bir problem olmayı sürdürmektedir. Bu bölgede açıkta süt satışı üzerinde önemle durulmalı ve toplum sağlığının korunması için gerekli tedbirler alınmalıdır.

\section{Ekler}

$\mathrm{Bu}$ araştırma HÜBAK tarafından desteklenmiş (Proje No: 13116) ve Öznur YAPIK'ın Yüksek Lisans Tezinden alınmıştır.

\section{Kaynaklar}

Alçiçek, A., 1995. Beslemenin süt yağına etkileri. Hasad Dergisi, 117: 32-34.

Anonim, 1989. Çiğ Süt Standardı. TS1018. Türk Standartlar Enstitüsü, Ankara. 
Anonim, 2008. Güvenli Süt Tüketimi Raporu. http://www.tetrapak.com.tr/pdf/ guvenli/ pdf.erişim: Aralık 2008.

Ateş, R., 2015. Türkiye Ölçeğinde Farklı Bölgelere Ait Özel Çiftlikler ve Üretici Birliklerinden Temin Edilen Çiğ Sütlerin Bileşiminde Yıl Boyunca Meydana Gelen Değişimlerin Belirlenmesi Üzerine Bir Araştırma. Namık Kemal Üniversitesi Fen Bilimleri Enstitüsü. Yüksek Lisans Tezi. Tekirdağ. 41s.

Aydın, S., Çetinkaya, A., Bayrakçı, E., 2010. Kars ilinde üretilen inek sütlerinin bazı kimyasal özellikleri. Ulusal Meslek Yüksekokulları Öğrenci Sempozyumu, 21- 22 Ekim 2010, Düzce.

Bek, Y., ve E. Efe, 1995. Araştırma ve Deneme Metotları. Ç.Ü. Ziraat Fakültesi Ders Notları No:71 Adana, 200s.

Çubuk, A., 1997. Ankara Piyasasında Tüketime Sunulan Süt ve Yoğurtların Protein,Yağ Kurumadde, Asitlik ve Kül Derecelerinin Saptanması. Yüksek Lisans Tezi. Hacettepe Üniversitesi Sağlık Bilimleri Enstitüsü Beslenme Bilimleri Programı, Ankara, 73s.

Dede, C., 2000. İstanbul'da Satılan Sokak Sütlerinin Mikrobiyolojik Olarak İncelenmesi. Gebze İleri Teknoloji Enstitüsü Mühendislik ve Fen Bilimleri Enstitüsü Biyoloji Anabilim Dalı Yüksek Lisans Tezi, 52s.

Demirci, M., Öksüz, Ö., Şimşek, O., Kurultay, Ş., Kıvanç, M., Gündüz, H.H., Uçan, N., 2010. Süt ve Süt Ürünlerinin Kalite Kontrolü. Anadolu Üniversitesi Yayın No: 2064. 254s.

Diler, A., ve Baran, A., 2014. Erzurum'un hınıs ilçesi çevresindeki küçük ölçekli işletme tank sütlerinden alınan çiğ süt örneklerinin bazı kalite özelliklerinin belirlenmesi. Alınteri Dergisi, 26 (B): 18-24.

Dozet, N., Stanisic, M., and Bijielzac, S., 1978. Studies on Quality of Milk in Various Regions of Production. 20. Int. Dairy Congr. P: 41-42.

Ergüllü, E., 1982. Çiğ sütte koliform grubu bakteri florası üzerinde araştırmalar, Gıda Dergisi, 6: 263-266.

Gönç, S., ve Tanülkü, B., 1981. Süt endüstrisi kurumu izmir fabrikasına gelen sütlerin bazı özelliklerine bölge ve mevsimlerin etkisi üzerine araştırmalar. E. Ü. Ziraat Fakültesi Dergisi 18 (1, 2, 3): 275-290

IDF., 1982. Determination of the Total Solid Content (CheeseandProcessedCheese). IDF Standard: 4A.Brussels: International DairyFederation.
IDF., 1993. MilkDetermination of Nitrogen Content. IDF Standard: 20B . Brussels: International DairyFederation..

Jaurez. M., Castro, M.I., Ramos, M., and Anvarez, M. P. J., 1978. Composition of milk in Spain. 1. MainComponente. Milchwissenschaft 33: 752-755.

Kaşıkçı, M., 2012. Sivas İli Yıldızeli illçesinde Halk Elinde Yetiştirilen Esmer Sığırların Çiğ Süt Kompozisyonu ve Somatik Hücre Sayısının Belirlenmesi. Gaziosmanpaşa Üniversitesi Fen Bilimleri Enstitüsü. Zootekni ABD, Tokat, $56 \mathrm{~s}$.

Kavas, G., ve Akbulut, N., 1993. İzmir ilinde satılan sokak sütlerinin fiziksel-kimyasal özellikleri üzerinde bir araştırma. E. Ü. Ziraat Fakültesi Dergisi, 30 (1-2): 81-88.

Kesenkaş, H., ve Akbulut., N., 2010. İzmir ilinde satılan sokak sütleri ile orta ve büyük ölçekli çiftliklerde üretilen sütlerin özelliklerinin belirlenmesi. Ege Üniversitesi Ziraat Fak. Dergisi, 2010, 47 (2): 161-169.

Kılıç, A., ve Kılıç, S., 1994. Yem(leme) ve Süt. Bilgehan Basımevi. Bornova, İzmir, 288s.

Köşker, Ö., ve Tunail, N., 1985. Süt ve Mamulleri Mikrobiyolojisi ve Hijyeni Uygulama Klavuzu. Ankara Üniversitesi Ziraat Fakültesi. Yay. No: 985, Uygulama Kılavuzu No: 217, Ankara.

Metin, M., 1998. Süt Teknolojisi, Ege Üniversitesi Mühendislik Fakültesi Yayınları No:33. Bornova, İzmir.

Metin, M., 2010. Süt ve Mamulleri Analiz Yöntemleri (Duyusal, Fiziksel ve Kimyasal Analizleri). Ege Üniversitesi Ege Meslek Yüksekokulu Yayınları No:24. Ege Meslek Yüksekokulu Basımevi, Bornova-Izmir, 439s.

Oysun, G., 2011. Süt ve Ürünlerinde Analiz Yöntemleri, Ege Üniversitesi Ziraat Fakültesi Yayınları No:504, Bornova- İzmir, $306 \mathrm{~s}$.

Önal, A. R., 2005. Trakya'da Özel Bir Süt İşleme Tesisi Tarafından Değerlendiren Çiğ Sütlerin Somatik Hücre Sayısı ve Bazı Bileşenlerin Tespiti. Trakya Üniversitesi Fen Bilimleri Enstitüsü Yüksek Lisans Tezi Zootekni Anabilim Dalı. 110s.

Özrenk, E., Bayar, N., 2008. Konya yöresine ait sütlerin bazı kalite özellikleri. Türkiye 10 . Gıda Kongresi. 21-23 Mayıs 2008, 695700s, Erzurum.

Özsunar, A., 2005. Trakya Bölgesinde Üretilen Inek Sütlerinde Aflatoksin M1 Varlığı. Yüksek Lisans Tezi. Trakya Üniversitesi Fen Bilimleri 
Enstitüsü Gıda Mühendisliği ABD, Tekirdağ, $50 \mathrm{~s}$.

Sezgin, E., Koçak, C., 1982. Ankara'da satılan sokak sütlerinin bazı nitelikleri üzerine araştırmalar. Gıda, 7(6): 281-287.

Sezgin, E., Bektaş, S., 1988. Trabzon'da Satılan Sokak Sütlerinin Bazı Nitelikleri Üzerine Araştırmalar, Gıda, 13(6):181-187.

Sezgin, E., Atamer, M., Koçak, C., Yıldırım, M., Yıldırım, Z., 1993. Ankara'da Satılan Sokak Sütlerinin Bazı Fiziksel, Kimyasal ve Mikrobiyolojik Özellikleri. A. Ü. Ziraat Fakültesi Yayınları 1331, Ankara.

Şekerden, Ö., Özkütük, K., 1995. Büyük Baş Hayvan Yetiştirme. Çukurova Üniversitesi Ziraat Fakültesi Ders Kitabı No: 122, Adana.

Tokur, E., 2006. Ankara'da satılan sokak sütlerinin bazı fiziksel ve kimyasal özelliklerinin belirlenmesi. Ankara Üniversitesi Fen Bilimleri Enstitüsü Süt Teknolojisi ABD., Ankara, 63s.

TUiK., 2014.Türkiye İstatistik Kurumu. Ankara.

Tuncer, K., 2015. TR71 Bölgesindeki Süt Sığırı İşletmelerinden Toplanan Çiğ Sütlerin Bazı Kalite Özelliklerinin Belirlenmesi/ Determination of Some Quality Characteristics of Raw Milk Samples Collected From Dairy Farms in TR71 Region. Ahi Evran Üniversitesi Fen Bilimleri Enstitüsü. Yüksek Lisans Tezi, Kırşehir, $77 \mathrm{~s}$.

Türkoğlu, H., Atasoy, F., Özer, B., 2003.Şanlıurfa Iilinde Üretilen ve Satışa Sunulan Süt, Yoğurt ve Urfa Peynirlerinin Bazı Kimyasal Özellikleri. GAP III. Tarım Kongresi, 16-18 Ekim 2003, 467-470s, Şanlıurfa.

Üzüm, M., 2006. Ankara Yöresinde Tüketime Sunulan Çiğ Sütlerde Salmonella, Shigella ve Bazı Patojenlerin İzolasyonu. Gazi Üniversitesi Fen Bilimleri Enstitüsü. Yüksek Lisans Tezi, Ankara, 73s.

Yalçın, B. C., 1981. Genel Zootekni (Ders Kitabı). İstanbul Üniversitesi Veteriner Fakültesi Yayınları. Rektörlük Yayın No: 2769. Dekanlık Yayın No:1.

Yaylak, E., Alçiçek, A., Konca, Y., Uysal, H., 2007. İzmir ilçelerinde mandıralarca kış aylarında toplanan sütlerde bazı besin madde ve fiziksel özelliklere ait değişimlerin saptanması. Hayvansal Üretim Dergisi. 48 (1): 26-32. 